\title{
Dilema Auditor: Faktor Internal dan Eksternal Independensi
}

\author{
Martdian Ratna Sari \\ Program Studi Akuntansi Bisnis, Sekolah Tinggi Manajemen PPM \\ Jl. Menteng Raya No.9, Kb. Sirih, Kec. Menteng, Kota Jakarta Pusat, Jakarta, Indonesia \\ martdianratnasari@gmail.com
}

\begin{abstract}
Alhamdi Zuhri
Program Studi Akuntansi Bisnis, Sekolah Tinggi Manajemen PPM

Jl. Menteng Raya No.9, Kb. Sirih, Kec. Menteng, Kota Jakarta Pusat, Jakarta, Indonesia alhamdizuhr@gmail.com

\section{Paulina Millennia Natalia Wijaya*}

Program Studi Akuntansi Bisnis, Sekolah Tinggi Manajemen PPM

Jl. Menteng Raya No.9, Kb. Sirih, Kec. Menteng, Kota Jakarta Pusat, Jakarta, Indonesia paulinamnw@gmail.com
\end{abstract}

Diterima: 09-02-2021

Disetujui: 16-06-2021

Dipublikasi: 30-06-2021

\begin{abstract}
ABSTRAK
Kebutuhan akan informasi keuangan menjadi salah satu komponen penting dalam perkembangan perekonomian. Auditor menjadi pihak yang menjamin bahwa laporan keuangan terjaga kredibilitasnya. Akan tetapi, terdapat banyak kasus yang menunjukkan penyalahgunaan laporan keuangan. Penelitian ini bertujuan untuk mengetahui pengaruh faktor internal dan faktor eksternal terhadap independensi auditor. Pada penelitian ini metode sampel menggunakan metode Purposive Sampling, yaitu dengan mengambil sampel dari populasi berdasarkan suatu kriteria tertentu (Sugiyono 2013). Kriteria sampel dalam penelitian ini adalah auditor yang telah memiliki pengalaman bekerja di KAP minimal 1 tahun. Jenis data yang digunakan adalah data primer berupa kuesioner. Penelitian ini membuktikan bahwa Lama hubungan auditor berpengaruh terhadap independensi auditor. Sedangkan penelitian ini tidak membuktikan bahwa Pemberian jasa non-audit, Persaingan antar KAP, Besar ukuran KAP, Jangka waktu audit, dan relativisme berpengaruh terhadap independensi auditor.
\end{abstract}

Kata Kunci:

Faktor Internal; Faktor Eksternal; Independensi Auditor

\begin{abstract}
The need for financial information is an important component of economic development. The auditor is the party that guarantees that the financial statements are maintained credibility. However, many cases show the misuse of financial statements. This study aims to determine the effect of internal and external factors on auditor independence. This study used a Purposive Sampling as the sampling method, which is by taking a sample from the population-based on certain criteria (Sugiyono, 2013). This study used a sample of the auditor who has experience working in the KAP for at least 1 year. The type of data used is primary data in the form of a questionnaire. This study proves that the length of the auditor's relationship influences auditor independence. While this study does not prove that the provision of non-audit services, Competition among KAP, Large size of $K A P$, Audit period, and Relativism influence the independence of auditors.
\end{abstract}

Keywords:

Internal Factors; External Factor; Auditor Independenc 


\section{PENDAHULUAN}

Salah satu komponen penting dari perkembangan perekonomian adalah kebutuhan akan informasi mengenai laporan keuangan. Laporan keuangan sangat penting bagi para penggunanya dalam mengambil keputusan, sehingga laporan keuangan harus terjaga kredibilitasnya dalam menyajikan informasi agar tidak mengurangi keyakinan dari pengguna laporan tersebut. Selain itu, laporan keuangan yang disajikan haruslah wajar, dapat dipercaya, serta dapat dipertanggung jawabkan. Salah satu peran akuntan publik dalam hal ini adalah memberikan jaminan kualitas laporan keuangan dan going concern suatu organisasi/perusahaan.

Profesi akuntan publik atau auditor merupakan profesi kepercayaan masyarakat, dimana seorang auditor dituntut bersikap objektif, jujur dan netral seperti yang dinyatakan dalam Standar Profesi Akuntan Publik (SPAP). Banyaknya orang yang memiliki kepentingan terhadap laporan keuangan mengharuskan seorang auditor mempertahankan independensinya. Namun, tidak menutup kemungkinan hasil auditing tersebut dipengaruhi hal-hal yang bertujuan untuk menyembunyikan kesalahan pada laporan keuangan sehingga laporan keuangan tersebut diragukan dan menurunkan kredibilitas auditor sebagai pihak yang independen.

Pada tahun 2018, Kementerian Keuangan menyatakan dua akuntan publik yang melakukan audit pada PT Sunprima Nusantara Pembiayaan (SNP) Finance telah melanggar standar audit profesional (cnnindonesia.com, 2018). Di tahun 2019 publik kembali dikejutkan dengan sanksi yang diberikan oleh Kementerian Keuangan terhadap Akuntan Publik (AP) Kasner Sirumapea dan Kantor Akuntan Publik (KAP) Tanubrata, Sutanto, Fahmi, Bambang \& Rekan, terkait permasalahan laporan keuangan Garuda Indonesia (ekonomi.bisnis.com, 2019). Disamping itu, Indonesia Corruption Watch (ICW) mencatat ada 252 kasus korupsi anggaran desa sepanjang tahun 2015-2018. Modus-modus yang ditemukan di antaranya penyalahgunaan anggaran, laporan fiktif, penggelapan, penggelembungan anggaran, dan suap.

Kasus-kasus tersebut merupakan sedikit dari banyaknya kasus yang menurunkan kepercayaan publik terhadap auditor. Posisi auditor sebagai pemberi opini terhadap laporan keuangan mulai dipertanyakan dengan didukung oleh bukti-bukti yang ada. Kurangnya independensi auditor membuat publik semakin mempertanyakan eksistensi auditor sebagai pihak yang independen. Selain itu, dengan terus meningkatnya dana desa yang diberikan oleh pemerintah maka sangat dibutuhkan auditor yang independen sehingga dapat memberikan opini yang sesuai. Independen berarti akuntan publik tidak mudah dipengaruhi, dan tidak berpihak karena akuntan publik melakukan pekerjaan untuk kepentingan umum.

Auditor yang memiliki independensi untuk memberikan opini sesuai dengan fakta yang ada pada saat pemeriksaan. Auditor dalam menjalani pekerjaannya hendaknya memperhatikan aturan dan kode etik yang berlaku. Aturan-aturan yang meliputi standar umum, prinsip akuntansi, integritas, tanggung jawab, dan objektivitas. Dalam hal etika, auditor harus memiliki komitmen yang tinggi pada suatu aturan khusus yang disebut sebagai etika profesi. Etika profesi merupakan sikap hidup berupa 
keadilan untuk memberikan pelayanan profesional terhadap masyarakat dengan penuh ketertiban dan keahlian sebagai pelayanan dalam rangka melaksanakan tugas berupa kewajiban terhadap masyarakat (Suhrawardi Lubis, 1994).

Terdapat beberapa faktor yang menjadi indikasi terhadap independensi auditor, baik dari sisi internal maupun eksternal. Dilihat dari sisi internal, faktor-faktor tersebut antara lain, 1.) Lama hubungan auditor dengan klien, 2.) Jangka waktu audit, 3.) Relativisme. Kemudian faktor-faktor yang dapat dilihat dari sisi eksternal diantaranya adalah 1.) Besar ukuran KAP, 2.) Persaingan KAP, 3.) Jasa non-audit. Implikasi dari penelitian ini diharapkan dapat menjadi pertimbangan dan evaluasi dalam praktik profesi Akuntan Publik di Indonesia demi peningkatan kinerja dan profesionalitas, serta mendukung usaha pengedukasian masyarakat, khususnya bagi para pemakai laporan keuangan.

\section{Profesi Akuntan Publik Sebagai Auditor}

Akuntan Publik adalah seorang praktisi dan gelar profesional yang diberikan kepada akuntan di Indonesia yang telah mendapatkan izin dari Menteri Keuangan RI (Peraturan Menteri Keuangan Nomor 17/PMK.01/2008 tentang Jasa Akuntan Publik). Akuntan publik memberikan jasa audit umum dan review atas laporan keuangan, audit kinerja dan audit khusus serta jasa dalam bidang non-atestasi lainnya seperti jasa konsultasi manajemen, jasa kompilasi, jasa akuntansi, jasa perpajakan, dan jasa-jasa lainnya yang berhubungan dengan akuntansi dan keuangan.

\section{Kode Etik Akuntan Publik}

Peran dan tanggung jawab dari seorang akuntan publik sangat penting dalam rangka melindungi kepentingan publik khususnya berupa ketersediaan informasi keuangan yang berkualitas. Oleh karena itu, setiap auditor harus mematuhi ketentuan Kode Etik Akuntan Publik. Dikutip dari Kode Etik Profesi Akuntan Publik yang diterbitkan oleh IAPI, terdapat 5 prinsip-prinsip dasar etika profesi, yaitu:

1. Prinsip Integritas, yaitu bersikap tegas dan jujur dalam semua hubungan profesional dan bisnis.

2. Prinsip Objektivitas, yaitu tidak membiarkan bias, benturan kepentingan, atau pengaruh yang tidak semestinya dari pihak lain, yang dapat memengaruhi pertimbangan profesional atau pertimbangan bisnisnya.

3. Prinsip Kompetensi serta Sikap Kecermatan dan Kehati-hatian Profesional, yaitu memiliki pengetahuan dan keahlian profesi pada tingkat yang diperlukan untuk memastikan bahwa klien atau pemberi kerja akan menerima jasa profesional yang kompeten berdasarkan perkembangan praktik, peraturan, dan metode pelaksanaan pekerjaan, serta bertindak sungguh-sungguh dan sesuai dengan metode pelaksanaan pekerjaan dan standar profesional yang berlaku

4. Prinsip Kerahasiaan, yaitu menjaga kerahasiaan informasi yang diperoleh sebagai hasil dari hubungan profesional dan hubungan bisnis dengan tidak mengungkapkan informasi tersebut kepada pihak ketiga tanpa adanya persetujuan dari klien atau pemberi kerja, kecuali terdapat kewajiban hukum atau hak profesional untuk mengungkapkan, serta tidak menggunakan informasi tersebut untuk keuntungan pribadinya atau pihak ketiga. 
5. Prinsip Perilaku Profesional, yaitu mematuhi peraturan perundang-undangan yang berlaku dan menghindari perilaku apapun yang mengurangi kepercayaan kepada profesi.

\section{Independensi Auditor}

Menurut Standar Profesi Akuntan Publik (SPAP) 2001 seksi 220.1 menyatakan bahwa "auditor diharuskan bersikap independen, artinya tidak mudah dipengaruhi, karena ia melaksanakan pekerjaannya untuk kepentingan umum.” Dengan begitu, seorang auditor diharuskan bersikap jujur dalam melaksanakan pekerjaannya dan tidak memiliki kepentingan terhadap siapapun termasuk pihak internal maupun eksternal. Selain itu, AICPA memberikan prinsip-prinsip sebagai panduan yang berkaitan dengan independensi, yaitu:

1. Auditor dan perusahaan tidak boleh tergantung dalam hak keuangan terhadap klien,

2. Auditor dan perusahaan seharusnya tidak terlibat dalam konflik kepentingan yang akan mengganggu objektivitas mereka berkenaan dengan cara-cara yang memengaruhi laporan keuangan,

3. Auditor dan perusahaan seharusnya tidak memiliki hubungan dengan klien yang akan mengganggu objektivitas auditor.

\section{Auditor Independen}

Auditor merupakan profesi kepercayaan publik. Selain itu, auditor sebagai pihak independen yang memberikan opini atas laporan keuangan harus menjalankan tugasnya dalam keadaan netral yang artinya tidak memihak dan dapat dipertanggung jawabkan. Laporan keuangan akan digunakan oleh banyak pihak. Oleh karena itu, auditor harus dapat mempertahankan independensinya agak kredibilitas laporan keuangan dapat terjaga sehingga pemangku keputusan dapat menentukan keputusan yang tepat bagi perusahaannya. Independence is generally understood to refer to the external auditor's mental state objectivity and lack of bias (Security and Exchange Commision, 2000).

\section{Faktor-Faktor Yang Dapat Memengaruhi Independensi}

1. Faktor internal adalah faktor yang berasal dari dalam diri seseorang atau individu itu sendiri, yang berupa sikap maupun sifat yang melekat pada diri seseorang.Berdasarkan penjelasan diatas maka Faktor internal terdiri atas:

a. Lama hubungan auditor dengan klien

Penelitian terdahulu yang meneliti masa perikatan audit yang dilakukan oleh Devy dan Dharma (2016) menunjukkan bahwa hubungan audit yang lama antara KAP dan klien berpengaruh positif terhadap independensi akuntan publik. Hal ini juga didukung oleh penelitian Kirana dan Hardi (2013) yang mengatakan audit tenure berpengaruh terhadap independensi auditor. 
b. Jangka waktu audit

Pembuatan taksiran kebutuhan waktu meliputi estimasi tentang jumlah jam yang diperkirakan dibutuhkan oleh setiap tingkat staf (partner, manajer, senior, dan sebagainya) untuk menyelesaikan setiap bagian audit dengan cermat dan seksama (Jusup, 2001).

\section{c. Relativisme}

Menurut hasil penelitian Cousin dan Ardiani (2010), auditor yang relativisme akan cenderung bersikap independen karena akan menolak prinsip moral yang bersifat universal atau absolut yang tidak sesuai dengan prinsip moral yang dimiliki oleh seorang auditor dan memiliki pandangan bahwa tidak ada standar etis yang secara absolute benar.

2. Faktor eksternal merupakan faktor yang mempengaruhi perilaku seseorang yang berasal dari luar dirinya atau dengan kata lain berasal dari lingkungan dimana orang tersebut berada. Berdasarkan penjelasan diatas maka faktor eksternal terdiri atas:

a. Besar ukuran KAP

Francis \& Yu (2009), menemukan semakin besar ukuran KAP, independensi auditor yang dihasilkan akan semakin tinggi. Kantor Akuntan Publik yang besar memiliki lebih banyak klien sehingga saat kehilangan satu klien tidak akan terlalu berdampak.

b. Persaingan KAP

Menurut Cousin dan Ardiani (2010) serta Ika S dan Ricky (2011) persaingan yang tajam antara kantor akuntan publik kemungkinan mempunyai pengaruh yang besar terhadap independensi akuntan publik.

c. Pemberian jasa non-audit

Adanya dua jenis jasa yang diberikan oleh suatu KAP yaitu jasa atestasi dan jasa nonatestasi dimana menjadikan independensi auditor terhadap kliennya dipertanyakan yang nantinya akan mempengaruhi independensi auditor (Elfarini, 2007).

\section{Pengembangan Hipotesis}

\section{Pemberian Jasa Non Audit}

Dalam memasarkan dan mempromosikan diri dan pekerjaannya, Akuntan Profesional dilarang mencemarkan nama baik profesi dengan bersikap jujur dan dapat dipercaya, serta tidak mengakui secara berlebihan mengenai jasa yang ditawarkan, kualifikasi yang dimiliki, atau pengalaman yang diperoleh (Kode Etik Akuntan Profesional; 150.2). Adanya dua jenis jasa yang diberikan oleh suatu KAP yaitu jasa atestasi dan jasa non-atestasi dimana menjadikan independensi auditor terhadap kliennya dipertanyakan yang nantinya akan mempengaruhi kualitas audit (Elfarini, 2007). Jasa atestasi meliputi jasa audit atas laporan keuangan historis pemeriksaan, dan penelaahan. Jasa non atestasi meliputi jasa akuntansi, jasa perpajakan, dan jasa akuntansi manajemen Halim (2008:18-19). Jasa tambahan diluar dari jasa audit semacam ini akan menciptakan hubungan kerja antara auditor dan klien yang terlalu dekat sehingga memberikan pengaruh terhadap independensi. 
H1: Pemberian jasa non-audit berpengaruh terhadap independensi.

\section{Lama Hubungan Auditor dengan Klien}

Keputusan Menteri Keuangan No.423/KMK.06/2002 telah membatasi lamanya hubungan auditor dengan klien, dimana masa kerja auditor paling lama 3 tahun untuk klien yang sama, sedangkan untuk Kantor Akuntan Publik (KAP) boleh sampai 5 tahun. Hal ini termasuk perilaku, yang menurut pihak ketiga yang rasional dan memiliki informasi yang cukup, setelah menimbang semua fakta dan keadaan tertentu yang tersedia bagi Akuntan Profesional pada waktu itu, akan menyimpulkan, yang mengakibatkan pengaruh negatif terhadap reputasi baik dari profesi. (Kode Etik Akuntan Profesional;150.1)

H2: Lama hubungan auditor dengan klien berpengaruh terhadap independensi.

\section{Persaingan antar Kantor Akuntan Publik}

Persaingan yang tajam dapat mengakibatkan solidaritas profesional yang rendah, hal ini disebabkan karena kantor akuntan publik khawatir akan mencari kantor akuntan publik lain yang dapat mengeluarkan opini sesuai dengan yang diinginkan klien (Cahyadi, 2013). Persaingan yang tajam antara kantor akuntan publik kemungkinan mempunyai pengaruh yang besar terhadap independensi akuntan publik. Persaingan KAP dapat menurunkan independensi auditor dikarenakan KAP satu dengan yang lainnya akan berusaha memberikan opini yang diinginkan oleh kliennya untuk mempertahankan klien tersebut.

H3: Persaingan antar Kantor Akuntan Publik berpengaruh terhadap independensi.

\section{Besar Ukuran Kantor Akuntan Publik}

Kantor Akuntan Publik dapat diukur berdasarkan jumlah kliennya ataupun besarnya audit fees. AICPA menggolongkan kantor akuntan publik yang besar jika sudah melakukan audit kepada perusahaan go-public. DeAngelo (1981) mendapatkan hasil yang menyatakan bahwa KAP besar (big 4 accounting firms) melakukan audit lebih berkualitas dibandingkan dengan KAP kecil (non big 4 accounting firms) yang dimana akan memengaruhi independensi. Francis \& Yu (2009), menemukan semakin besar ukuran KAP, independensi auditor yang dihasilkan akan semakin tinggi. Kantor Akuntan Publik yang besar memiliki lebih banyak klien sehingga saat kehilangan satu klien tidak akan terlalu berdampak. Namun, kondisi yang berbeda ketika KAP kecil kehilangan kliennya. KAP kecil akan berusaha mempertahankan kliennya karena satu klien akan sangat berdampak bagi KAP tersebut. H4: Ukuran Kantor Akuntan Publik berpengaruh terhadap independensi.

\section{Jangka Waktu Audit dengan Independensi Auditor}

Dalam mempertimbangkan penerimaan penugasan, auditor biasanya membuat suatu taksiran kebutuhan waktu audit sebagai bagian dari pertimbangan dalam penjadwalan. Pembuatan taksiran kebutuhan waktu meliputi estimasi tentang jumlah jam yang diperkirakan dibutuhkan oleh setiap tingkat staf (partner, manajer, senior, dan sebagainya) untuk menyelesaikan setiap bagian audit dengan cermat 
dan seksama (Jusup, 2001). Jangka waktu audit yang lama dapat mempererat hubungan auditor dengan klien diikuti dengan semakin banyaknya fasilitas yang diberikan oleh klien kepada auditor sehingga memengaruhi independensi auditor tersebut.

H5: Jangka waktu audit berpengaruh terhadap independensi.

\section{Relativisme}

Relativisme adalah suatu sikap penolakan terhadap nilai-nilai moral yang absolute dalam mengarahkan perilaku etis. Menurut hasil penelitian Cousin dan Ardiani (2010), auditor yang relativisme akan cenderung bersikap independen karena akan menolak prinsip moral yang bersifat universal atau absolut yang tidak sesuai dengan prinsip moral yang dimiliki oleh seorang auditor dan memiliki pandangan bahwa tidak ada standar etis yang secara absolute benar. Jika seorang auditor memiliki sikap sesuai dengan etika profesi yang berlaku, maka kualitas auditor yang dihasilkan semakin baik.

H6: Relativisme berpengaruh terhadap independensi.

\section{METODE RISET}

\section{Jenis Penelitian}

Jenis penelitian ini adalah kuantitatif dengan pendekatan eksplanatif. Penelitian kuantitatif adalah jenis penelitian yang menggunakan proses data-data yang berupa angka sebagai alat menganalisis dan melakukan kajian penelitian, terutama mengenai apa yang sudah diteliti (Kasiram, 2008). Menurut Bungin (2010) penelitian eksplanatif dimaksudkan untuk menjelaskan suatu generalisasi sampel terhadap populasinya atau menjelaskan hubungan, perbedaan, atau pengaruh suatu variabel dengan variabel lain.

\section{Jenis Data dan Sumber Data}

Sumber data yang digunakan dalam penelitian ini adalah data primer. Data primer adalah data yang diperoleh atau dikumpulkan langsung oleh informan yang memberikan data kepada pengumpul data (Sugiyono, 2010). Data primer dalam penelitian ini yaitu pertanyaan tertulis berupa kuesioner yang disebar secara offline maupun online. Data primer yang akan diteliti yaitu persepsi auditor akan faktorfaktor yang berkaitan terhadap independensi auditor dengan karakteristik responden yang telah ditentukan.

\section{Populasi dan Sampel}

Populasi yang digunakan dalam penelitian ini adalah auditor yang bekerja pada KAP di wilayah Jabodetabek. Teknik sampling yang digunakan dalam penelitian ini dilakukan dengan teknik purposive sampling, yaitu dilakukan dengan mengambil sampel dari populasi berdasarkan suatu kriteria tertentu (Sugiyono, 2013). Kriteria dalam penelitian ini adalah auditor yang telah memiliki pengalaman bekerja di KAP minimal 1 tahun. Hal ini dimaksudkan agar auditor telah memiliki pengalaman sehingga data yang akan dihasilkan kuesioner benar adanya. 


\section{Metode Pengumpulan Data}

Menurut Riduwan (2010) pengertian dari teknik pengumpulan data adalah teknik atau cara-cara yang dapat digunakan oleh peneliti untuk mengumpulkan data. Sedangkan menurut Djaman Satori dan Aan Komariah (2011) pengertian teknik pengumpulan data dalam penelitian ilmiah adalah prosedur sistematis untuk memperoleh data yang diperlukan. Adapun teknik pengumpulan data yang dilakukan dalam penelitian ini yaitu metode dokumentasi dan metode studi pustaka. Nana Syaodih (2012) mengemukakan bahwa metode dokumentasi merupakan suatu teknik pengumpulan data dengan menghimpun dan menganalisis dokumen-dokumen, baik dokumen tertulis, gambar maupun elektronik. Sedangkan menurut Nazir (2013) metode pustaka merupakan teknik pengumpulan data dengan mengadakan studi penelaah terhadap buku-buku, literatur-literatur, catatan-catatan, dan laporan-laporan yang ada hubungannya dengan masalah yang dipecahkan.

\section{Variabel Penelitian}

Penelitian ini akan menguji pengaruh antara beberapa variabel bebas (variabel independen) dan satu variabel terikat (variabel dependen). Variabel terikat atau dependent variable merupakan variabel yang dipengaruhi atau yang menjadi akibat, karena adanya variabel bebas (Sugiyono, 2014). Variabel terikat (variabel dependen) yang digunakan dalam penelitian ini adalah Independensi Auditor dilambangkan dengan huruf Y. Adapun variabel bebas (variabel independen) adalah; Pemberian jasa non-audit (X1), Lama hubungan auditor dengan klien (X2), Persaingan antar KAP (X3), Besar ukuran KAP (X4), Jangka waktu audit (X5), Relativisme (X6).

\section{Definisi Operasional}

Menurut Sugiyono (2014) definisi operasional adalah penentuan konstruk atau sifat yang akan dipelajari sehingga menjadi variabel yang dapat diukur. Definisi operasional dapat dikatakan sebagai cara untuk memberikan ukuran serta mengukur setiap variabel yang digunakan dengan merumuskan secara singkat dan jelas, serta tidak menimbulkan berbagai tafsiran Mustofa (2011). Berdasarkan rumusan masalah yang diteliti maka variabel dalam penelitian ini akan dikelompokkan dalam dua jenis variabel, yaitu:

\section{Variabel Dependen}

Variabel terikat (variabel dependen) adalah tipe variabel yang dapat dipengaruhi oleh variabel lainnya, variabel dependen dalam penelitian ini dilambangkan dengan huruf Y yaitu Independensi Auditor. Independensi auditor merupakan bentuk sikap yang harus dimiliki auditor yaitu seorang auditor dituntut bersikap objektif, jujur dan netral seperti yang dinyatakan dalam Standar Profesi Akuntan Publik (SPAP). Dalam menjalankan tugasnya, independensi auditor akan menjadi tolak ukur untuk kredibilitas auditor sebagai pihak yang independen. "Auditor yang independen adalah auditor yang tidak dipengaruhi oleh berbagai kekuatan yang berasal dari luar diri auditor dalam mempertimbangkan fakta yang dijumpainya dalam audit” (Islahuzzaman, 2012). 


\section{Variabel Independen}

Variabel bebas (variabel independen) adalah tipe variabel yang tidak dapat dipengaruhi oleh variabel lainnya, variabel bebas dilambangkan dengan huruf X. Definisi operasional variabel bebas (variabel independen) sebagai berikut:

a. Pemberian Jasa Non Audit. (X1)

Adanya dua jenis jasa yang diberikan oleh suatu KAP yaitu jasa atestasi dan jasa nonatestasi dimana menjadikan independensi auditor terhadap kliennya dipertanyakan yang nantinya akan mempengaruhi independensi auditor (Elfarini, 2007). Jasa atestasi meliputi jasa audit atas laporan keuangan historis pemeriksaan, dan penelaahan. Jasa non atestasi meliputi jasa akuntansi, jasa perpajakan, dan jasa akuntansi manajemen Halim (2008:18-19). Jasa tambahan diluar dari jasa audit semacam ini akan menciptakan hubungan kerja antara auditor dan klien yang terlalu dekat sehingga memberikan pengaruh terhadap independensi.

b. Lama hubungan auditor dengan klien (X2)

Keputusan Menteri Keuangan No.423/KMK.06/2002 telah membatasi lamanya hubungan auditor dengan klien, dimana masa kerja auditor paling lama 3 tahun untuk klien yang sama, sedangkan untuk Kantor Akuntan Publik (KAP) boleh sampai 5 tahun.

c. Persaingan antar Kantor Akuntan Publik (X3)

Persaingan yang tajam dapat mengakibatkan solidaritas profesional yang rendah, hal ini disebabkan karena kantor akuntan publik khawatir akan mencari kantor akuntan publik lain yang dapat mengeluarkan opini sesuai dengan yang diinginkan klien (Cahyadi, 2013). Persaingan yang tajam antara kantor akuntan publik kemungkinan mempunyai pengaruh yang besar terhadap independensi akuntan publik.

d. Ukuran Kantor Akuntan Publik (X4)

Kantor Akuntan Publik dapat diukur berdasarkan jumlah kliennya ataupun besarnya audit fees. AICPA menggolongkan kantor akuntan publik yang besar jika sudah melakukan audit kepada perusahaan go-public. DeAngelo (1981) mendapatkan hasil yang menyatakan bahwa KAP besar (big 4 accounting firms) melakukan audit lebih berkualitas dibandingkan dengan KAP kecil (non big 4 accounting firms) dan dapat disimpulkan dengan kualitas audit yang tinggi maka independensi auditor semakin tinggi. Francis \& Yu (2009), menemukan semakin besar ukuran KAP, independensi seorang auditor akan semakin tinggi.

e. Jangka waktu audit (X5)

Dalam mempertimbangkan penerimaan penugasan, auditor biasanya membuat suatu taksiran kebutuhan waktu audit sebagai bagian dari pertimbangan dalam penjadwalan. Pembuatan taksiran kebutuhan waktu meliputi estimasi tentang jumlah jam yang diperkirakan dibutuhkan oleh setiap tingkat staf (partner, manajer, senior, dan 
sebagainya) untuk menyelesaikan setiap bagian audit dengan cermat dan seksama (Jusup, 2001).

f. Relativisme (X6)

Relativisme adalah suatu sikap penolakan terhadap nilai-nilai moral yang absolute dalam mengarahkan perilaku etis. Menurut hasil penelitian Cousin dan Ardiani (2010), auditor yang relativisme akan cenderung bersikap independen karena akan menolak prinsip moral yang bersifat universal atau absolut yang tidak sesuai dengan prinsip moral yang dimiliki oleh seorang auditor dan memiliki pandangan bahwa tidak ada standar etis yang secara absolute benar. Jika seorang auditor memiliki sikap sesuai dengan etika profesi yang berlaku, maka kualitas auditor yang dihasilkan semakin baik.

\section{HASIL PENELITIAN DAN PEMBAHASAN}

\section{Analisis Statistik Deskriptif}

Responden dalam penelitian ini merupakan auditor junior dan auditor senior yang memiliki pengalaman bekerja sebagai auditor di KAP minimal 1 tahun. Target penyebaran kuesioner dalam penelitian ini adalah 100 kuesioner. Data yang berhasil tersebar sebanyak 46 kuesioner dan yang berhasil diisi oleh responden yaitu sebanyak 42 kuesioner.

\section{Analisis Hasil Uji Statistik Deskriptif}

Tabel 1. Hasil Uji Statistik Deskriptif

\begin{tabular}{lcccc}
\hline \multicolumn{1}{c}{ Variabel } & Minimum & Maximum & Mean & Std. Deviation \\
\hline Jasa Non Audit & 2,00 & 10,00 & 7,0952 & 1,66469 \\
Lama Hubungan Auditor & 4,00 & 10,00 & 7,3810 & 1,39603 \\
Dengan Klien & & & & \\
Persaingan KAP & 4,00 & 20,00 & 12,2619 & 2,36911 \\
Besar Ukuran KAP & 6,00 & 20,00 & 13,5476 & 2,32906 \\
Jangka Waktu Audit & 4,00 & 10,00 & 5,9286 & 1,73054 \\
Relativisme & 10,00 & 20,00 & 15,1190 & 2,16629 \\
Independensi Auditor & 22,00 & 35,00 & 29,3333 & 3,86142 \\
\hline
\end{tabular}

Sumber: Hasil olah data penulis

Variabel jasa non audit mempunyai bobot jawaban antara 2 sampai dengan 10, rata-rata (mean) sebesar 7,09 dan standar deviasi 1,66, menunjukan tidak ada kesenjangan yang cukup besar pada karakteristik personal responden, sehingga dapat disimpulkan bahwa secara umum karakteristik personal responden memiliki persepsi tentang jasa non audit yang tinggi. Variabel lama hubungan auditor dengan klien mempunyai bobot jawaban antara 4 sampai dengan 10, rata-rata (mean) sebesar 7,38 dan standar deviasi 1,39 yang menunjukan tidak ada kesenjangan yang cukup besar pada karakteristik personal responden, sehingga dapat disimpulkan bahwa secara umum karakteristik personal responden memiliki persepsi tentang lama hubungan auditor dengan klien yang tinggi. 
Variabel persaingan KAP mempunyai bobot jawaban antara 4 sampai dengan 20, rata-rata (mean) sebesar 12,26 dan standar deviasi 2,36 yang menunjukan tidak ada kesenjangan yang cukup besar pada karakteristik personal responden, sehingga dapat disimpulkan bahwa secara umum karakteristik personal responden memiliki persepsi tentang persaingan KAP yang tinggi. Variabel besar ukuran KAP mempunyai bobot jawaban antara 6 sampai dengan 20, rata-rata (mean) sebesar 13,54 dan standar deviasi 2,32 yang menunjukan tidak ada kesenjangan yang cukup besar pada karakteristik personal responden, sehingga dapat disimpulkan bahwa secara umum karakteristik personal responden memiliki persepsi tentang besar ukuran KAP yang tinggi. Variabel jangka waktu audit mempunyai bobot jawaban antara 4 sampai dengan 10, rata-rata (mean) sebesar 5,92 dan standar deviasi 2,73 yang menunjukan tidak ada kesenjangan yang cukup besar pada karakteristik personal responden, sehingga dapat disimpulkan bahwa secara umum karakteristik personal responden memiliki persepsi tentang jangka waktu audit KAP yang tinggi. Variabel relativisme mempunyai bobot jawaban antara 10 sampai dengan 20, rata-rata (mean) sebesar 15,11 dan standar deviasi 2,16 yang menunjukan tidak ada kesenjangan yang cukup besar pada karakteristik personal responden, sehingga dapat disimpulkan bahwa secara umum karakteristik personal responden memiliki persepsi tentang relativisme yang tinggi. Variabel independensi auditor mempunyai bobot jawaban antara 22 sampai dengan 35, rata-rata (mean) sebesar 29,33 dan standar deviasi 3,86 yang menunjukan tidak ada kesenjangan yang cukup besar pada karakteristik personal responden, sehingga dapat disimpulkan bahwa secara umum karakteristik personal responden memiliki persepsi tentang independensi auditor yang tinggi.

\section{Analisis Hasil Uji Normalitas}

Tabel 2. Hasil Uji Normalitas

One-Sample Kolmogrov-Smirnov Test

\begin{tabular}{lr}
\hline \multicolumn{2}{r}{ Unstandardized Residual } \\
\hline $\mathrm{N}$ & $\mathbf{4 2}$ \\
Test Statistic & $\mathbf{0 7 1}$ \\
Asymp. Sig. (2-tailed) & $\mathbf{. 0 0}$ \\
\hline \multicolumn{2}{c}{ Sumber: Hasil olah data penulis }
\end{tabular}

Berdasarkan Tabel diatas dapat disimpulkan bahwa nilai signifikansi Kolmogrov Smirnov lebih besar dari $\alpha=0,05$ yaitu sebesar 0,200. Oleh karena itu, dapat disimpulkan bahwa data yang digunakan terdistribusi dengan normal.

\section{Analisis Hasil Uji Heteroskedastisitas}

Berdasarkan tabel dibawah ini setiap variabel independen yaitu Jasa non-audit, Lama hubungan auditor dengan klien, persaingan KAP, Besar ukuran KAP, Jangka waktu audit, dan Relativisme secara statistik tidak memengaruhi variabel dependen yaitu Independensi auditor. Hal ini dilihat dari nilai signifikansi yang lebih besar dari tingkat kepercayaan 5\% atau 0,05. Oleh karena itu, dapat disimpulkan bahwa tidak terjadi heteroskedastisitas. 
Tabel 3. Hasil Uji Heteroskedastisitas

\begin{tabular}{|c|c|c|c|c|c|}
\hline \multirow[b]{2}{*}{ Model } & \multicolumn{2}{|c|}{$\begin{array}{l}\text { Unstandardized } \\
\text { Coefficients }\end{array}$} & \multirow{2}{*}{$\begin{array}{c}\text { Standardized } \\
\text { Coefficients } \\
\text { Beta }\end{array}$} & \multirow[b]{2}{*}{$\mathrm{t}$} & \multirow[b]{2}{*}{ Sig. } \\
\hline & B & Std. Error & & & \\
\hline 1 (Constant) & 5.853 & 2.640 & & 2.217 & .033 \\
\hline Jasa Non-Audit & .441 & .201 & .400 & 2.195 & .035 \\
\hline $\begin{array}{l}\text { Lama Hubungan Auditor } \\
\text { Dengan Klien }\end{array}$ & -.136 & .237 & -.103 & -.576 & .568 \\
\hline Persaingan KAP & -.032 & .162 & -.041 & -.196 & .846 \\
\hline Besar Ukuran KAP & -.027 & .139 & -.035 & -.197 & .845 \\
\hline Jangka Waktu Audit & -.065 & .196 & -.065 & -.333 & .741 \\
\hline Relativisme & -.277 & .151 & -.326 & -.1833 & .075 \\
\hline
\end{tabular}

Sumber: Hasil olah data penulis

\section{Analisis Hasil Uji Multikolinearitas}

\begin{tabular}{llcc}
\multicolumn{5}{c}{ Tabel 4. Hasil Uji Multikolineritas } \\
\hline & \multicolumn{2}{c}{ Collinearity Statistics } \\
\hline Model & Tolerance & VIF \\
\hline $1 \quad$ (Constant) & & \\
& & .703 & 1.422 \\
& Jasa Non-Audit & .723 & 1.382 \\
& Lama Hubungan Auditor Dengan Klien & .538 & 1.858 \\
& Persaingan KAP & .750 & 1.333 \\
& Besar Ukuran KAP & .623 & 1.604 \\
& Jangka Waktu Audit & .737 & 1.356 \\
& Relativisme & &
\end{tabular}

Sumber: Hasil olah data penulis

Berdasarkan tabel diatas setiap variabel independen yaitu Jasa non-audit, Lama hubungan auditor dengan klien, persaingan KAP, Besar ukuran KAP, Jangka waktu audit, dan Relativisme secara statistik tidak terjadi interkorelasi dengan variabel dependen yaitu Independensi auditor. Hal ini dapat disimpulkan dari nilai Tolerance $>0,1$ dan nilai $V I F<10$.

\section{Analisis Hasil Uji Autokorelasi}

Tabel 5. Hasil Uji Autokorelasi

\begin{tabular}{ccccc}
\hline $\mathrm{R}$ & $\mathrm{R}$ Square & $\begin{array}{c}\text { Adjusted R } \\
\text { Square }\end{array}$ & $\begin{array}{l}\text { Std. Error of } \\
\text { the Estimate }\end{array}$ & Durbin-Watson \\
\hline $.539^{a}$ & .290 & .168 & 3.522 & 1.303 \\
& & \\
Predictors: (Constant), Jasa Non-Audit, Lama Hubungan Auditor Dengan Klien, \\
Persaingan KAP, Besar Ukuran KAP, Jangka Waktu Audit, Relativisme
\end{tabular}

Sumber: Hasil olah data penulis 
Sari, M.R., Zuhri, A. \& Wijaya, P.M.N. (2021). Dilema Auditor: Faktor Internal ....

\begin{tabular}{|c|c|c|c|c|}
\hline \multicolumn{5}{|c|}{ Tabel 6. Hasil Durbin Watson } \\
\hline $\bar{d}$ & dl & du & 4-dl & 4-du \\
\hline 1,303 & 1,2022 & 1,8451 & 2,7978 & 2,1549 \\
\hline
\end{tabular}

Berdasarkan tabel diatas dapat disimpulkan bahwa nilai Durbin Watson sebesar 1,303 dengan jumlah variabel independen $6(\mathrm{~K}=6)$, dan nilai pembanding signifikansi $5 \%(0,05)$.sehingga didapatkan nilai dL sebesar 1,2022 dan nilai dU sebesar 1,8541.Dikarenakan $\mathrm{dl}<\mathrm{d}<\mathrm{du}$ maka uji Autokorelasi tidak dapat disimpulkan.

\section{Uji Hipotesis}

\section{Analisis Hasil Uji Koefisien Determinasi $\left(\mathbf{R}^{2}\right)$}

Tabel 7. Hasil Uji Koefisien Determinasi $\left(\mathbf{R}^{2}\right)$

\begin{tabular}{ccccc}
\hline Model & R & R Square & $\begin{array}{c}\text { Adjusted R } \\
\text { Square }\end{array}$ & $\begin{array}{c}\text { Std. Error of } \\
\text { the Estimate }\end{array}$ \\
\hline 1 &, $543^{\mathrm{a}}$ &, 295 &, 174 & 3,50962 \\
\hline \multicolumn{4}{c}{ Sumber: Hasil olah data penulis }
\end{tabular}

Berdasarkan hasil dari tabel diatas, nilai koefisien determinasi yang ditunjukkan dengan nilai adjusted $R$ square adalah sebesar 0,295 yang dapat diartikan bahwa variabel dependen yaitu jasa nonaudit, lama hubungan auditor dengan klien, persaingan KAP, besar ukuran KAP, jangka waktu audit, dan relativisme secara keseluruhan menjelaskan independensi auditor sebesar 29,5\% sedangkan sisanya sebesar 70,5\% diterangkan oleh faktor lain yang tidak diamati dalam penelitian ini.

\section{Analisis Hasil Uji F}

Tabel 8. Hasil Uji F

\begin{tabular}{lccccc}
\hline & Sum of Squares & df & Mean Square & F & Sig. \\
\hline Regression & 180,223 & 6 & 30,037 & 2,439 &, $045^{b}$ \\
Residual & 431,111 & 35 & 12,317 & & \\
Total & 611,333 & 41 & & & \\
\hline
\end{tabular}

Sumber: Hasil olah data penulis

Berdasarkan hasil dari tabel diatas, nilai signifikansi F sebesar 0,045 $<0,05$. Sehingga dapat disimpulkan bahwa semua variabel yaitu jasa non-audit, lama hubungan auditor dengan klien, persaingan KAP, besar ukuran KAP, jangka waktu audit, dan relativisme secara bersama-sama berpengaruh terhadap independensi, sehingga model regresi dikatakan layak atau fit (goodness of fit).

\section{Analisis Hasil Uji T}

Hasil dari tabel diatas menunjukan bahwa variabel lama hubungan auditor dengan klien berpengaruh positif terhadap variabel $\mathrm{Y}$ karena $0,005<0,05$, sedangkan untuk variabel jasa non-audit, persaingan KAP, besar ukuran KAP, jangka waktu audit, dan relativisme tidak berpengaruh terhadap independensi auditor 
Tabel 9. Hasil Uji T

\begin{tabular}{|c|c|c|c|c|c|}
\hline & \multicolumn{2}{|c|}{ Unstandardized Coefficients } & \multirow{2}{*}{$\begin{array}{c}\begin{array}{c}\text { Standardized } \\
\text { Coefficients }\end{array} \\
\text { Beta } \\
\end{array}$} & \multirow[b]{2}{*}{ t } & \multirow[b]{2}{*}{ Sig. } \\
\hline & B & Std. Error & & & \\
\hline (Constant) & 17,296 & 5,128 & & 3,373 &, 002 \\
\hline Jasa Non Audit &,- 242 & ,393 &,- 105 &,- 618 &, 541 \\
\hline Lama Hubungan Auditor & 1,388 & ,461 &, 502 & 3,009 &, 005 \\
\hline \multicolumn{6}{|l|}{ Dengan Klien } \\
\hline Persaingan KAP &,- 095 &, 320 &,- 058 &,- 297 &, 768 \\
\hline Besar Ukuran KAP &,- 312 &, 271 &,- 188 & $-1,148$ &, 259 \\
\hline Jangka Waktu Audit & ,296 & ,405 &, 133 & ,733 & ,469 \\
\hline Relativisme &, 472 & ,291 & 265 & 1,622 &, 114 \\
\hline
\end{tabular}

Berdasarkan tabel 10 yaitu hasil dari uji $\mathrm{T}$, berikut penjelasan dan pembahasan dari masing-masing variabel:

\section{Jasa non-audit terhadap independensi auditor}

Berdasarkan hasil pengolahan data diatas, pengaruh variabel jasa non-audit terhadap independensi auditor diperoleh nilai $t$ hitung $<\mathrm{t}$ tabel yaitu $-0,618<2,026$, dengan nilai signifikansi $0,541>0,05$. Maka dapat dikatakan bahwa jasa non-audit tidak memiliki pengaruh yang signifikan terhadap independensi auditor. Pemberian jasa non-audit seperti penyusunan sistem akuntansi, jasa konsultasi perpajakan, dan jasa manajemen lain akan memberikan akses informasi yang lebih kepada auditor. Sehingga auditor semakin memahami klien. Pemahaman tersebut akan menjadikan auditor memiliki kekuatan untuk mempertahankan independensinya. Hasil penelitian ini konsisten dengan penelitian Akbar \& Kartika (2015) yang menyatakan pemberian jasa non-audit tidak berpengaruh terhadap independensi auditor. Hal ini dikarenakan Auditor yang memberikan jasa non-audit akan memperoleh keyakinan yang lebih tinggi terhadap informasi yang disajikan dan tetap bersikap profesional sesuai dengan kode etik yang berlaku.

\section{Lama hubungan auditor dengan klien}

Berdasarkan hasil pengolahan data diatas, pengaruh variabel lama hubungan auditor dengan klien terhadap independensi auditor diperoleh $\mathrm{t}$ hitung $>\mathrm{t}$ tabel dengan nilai signifikansi $0,005<0,05$. Maka dapat dikatakan bahwa lama hubungan auditor berpengaruh signifikan terhadap independensi auditor. Auditor yang telah mengenal klien dalam jangka waktu yang lama dapat mempererat hubungan diantara keduanya. Hubungan tersebut memungkinkan untuk auditor dan klien menjadi rekan kerja. Dengan begitu, auditor tentu ingin memberikan opini yang dapat menguntungkan kedua belah pihak. Hubungan yang erat juga dapat menimbulkan keputusan-keputusan yang didasari oleh empati atau perasaan tertentu auditor terhadap klien. Sehingga dapat dikatakan auditor cenderung memberikan opini yang mengikuti keinginan klien ataupun tidak sesuai dengan kondisi klien. Hasil penelitian ini konsisten dengan penelitian Putri et al (2014) yang menyatakan lama hubungan auditor berpengaruh terhadap independensi auditor. 


\section{Persaingan KAP}

Berdasarkan hasil pengolahan data diatas, pengaruh variabel persaingan KAP terhadap independensi auditor diperoleh nilai $\mathrm{t}$ hitung $<\mathrm{t}$ tabel yaitu $-0,297<2,026$, dengan nilai signifikansi $0,768>0,05$. Maka dapat dikatakan bahwa persaingan KAP tidak memiliki pengaruh yang signifikan terhadap independensi auditor. Tingkat persaingan antar KAP yang tinggi tidak menjadikan seorang auditor mengikuti keinginan klien. Hal ini berkaitan dengan kode etik profesi yang menjadi dasar auditor dalam bertindak.Auditor memiliki tanggung jawab untuk memberikan opini yang sebenarbenarnya.Selain itu, auditor tetap harus menjaga kepercayaan publik. Jika auditor mengikuti keinginan klien dengan tujuan mempertahankannya, maka akan menimbulkan risiko KAP yang kehilangan kepercayaan publik.Dalam berbisnis, suatu organisasi tentu ingin mendapatkan dukungan publik, apabila organisasi tersebut menggunakan KAP yang meragukan di mata publik, tentu tidak akan berdampak baik terhadap organisasi itu sendiri. Hasil penelitian ini konsisten dengan penelitian yang dilakukan oleh Rakai A.W.S \& Kartika (2015) yang menyatakan bahwa auditor tetap memiliki etika profesi yang berlaku dalam persaingan antar KAP baik tajam maupun tidak tajam sehingga tidak mempengaruhi opini yang akan disampaikan oleh auditor.

\section{Besar ukuran KAP}

Berdasarkan hasil pengolahan data diatas, pengaruh variabel besar ukuran KAP terhadap independensi auditor diperoleh nilai $\mathrm{t}$ hitung $<\mathrm{t}$ tabel yaitu $-1,148<2,026$, dengan nilai signifikansi $0,259>0,05$. Maka dapat dikatakan bahwa persaingan KAP tidak memiliki pengaruh yang signifikan terhadap independensi auditor. Dengan demikian, auditor yang bekerja pada KAP skala besar tidak menjamin bahwa auditor tersebut memiliki independensi yang tinggi. Begitupun sebaliknya, KAP yang berskala kecil tidak menentukan seberapa tinggi tingkat independensi dari auditor tersebut. Auditor pada dasarnya harus memberikan opini yang sewajar-wajarnya. Namun, di setiap KAP tentu memiliki tekanan, kesempatan, dan rasionalisasi yang berbeda terkait kecurangan. Oleh karena itu, kecurangan yang dapat terjadi tidak dapat digeneralisasikan dari besar ukuran KAP. Selain itu, KAP yang berskala kecil dapat menekankan independensi dan profesionalitasnya terhadap auditor agar mendapatkan kepercayaan publik yang lebih besar atau KAP yang berskala besar dapat menekankan independensi dan profesionalitasnya terhadap auditor agar mampu mempertahankan kepercayaan publik yang telah dimiliki. Hasil penelitian ini tidak mendukung penelitian yang dilakukan oleh Akbar \& Kartika (2015) yang menyatakan bahwa ukuran KAP yang besar akan lebih berhati-hati dalam menjaga reputasi dari KAP tersebut sehingga menjamin independensi auditor di KAP tersebut.

\section{Jangka waktu audit}

Berdasarkan hasil pengolahan data diatas, pengaruh variabel jangka waktu audit terhadap independensi auditor diperoleh nilai $\mathrm{t}$ hitung $<\mathrm{t}$ tabel yaitu $0,733<2,026$, dengan nilai signifikansi 0 , $469>0,05$. Maka dapat disimpulkan bahwa jangka waktu audit tidak berpengaruh kuat terhadap independensi auditor. Dalam pelaksanaan audit, auditor dituntut untuk dapat memberikan opini yang 
sesuai dengan waktu yang singkat dan biaya yang terbatas. Selain itu, auditor juga diharuskan untuk mengumpulkan bukti-bukti sebagai dasar pemberian opini. Jangka waktu audit yang lama akan memungkinkan auditor untuk menemukan bukti audit yang lebih banyak dan berkualitas. Hal tersebut dapat meningkat keyakinan auditor terhadap opini yang akan diberikan. Oleh karena itu, dengan tanggung jawab dan keyakinan yang dimiliki oleh auditor tidak menjadikan seorang auditor menurunkan independensinya terhadap klien. Hasil penelitian ini tidak mendukung hasil penelitian yang dilakukan oleh Wurangian dan Anshori (2006) yang menyatakan bahwa jangka waktu audit secara parsial berpengaruh terhadap independensi auditor.

\section{Relativisme}

Berdasarkan hasil pengolahan data diatas, pengaruh variabel relativisme terhadap independensi auditor diperoleh nilai $\mathrm{t}$ hitung $<\mathrm{t}$ tabel yaitu 1,622 <2,026, dengan nilai signifikansi 0,114 $>0,05$. Maka dapat disimpulkan bahwa relativisme tidak memiliki pengaruh yang signifikan terhadap independensi auditor. Dengan demikian auditor yang memiliki relativisme yang tinggi tidak mempengaruhi sikap independensi karena auditor menerima bahwa prinsip moral yang dimilikinya sesuai dengan prinsip moral berlaku secara universal. Hasil penelitian ini tidak mendukung penelitian yang dilakukan oleh Probowati (2015) yang mengatakan bahwa auditor yang memiliki relativisme yang tinggi akan cenderung bersikap independen karena menolak prinsip moral yang bersifat universal atau absolut dan memiliki pandangan bahwa tidak ada standar etis yang absolut benar.

\section{KESIMPULAN DAN SARAN}

\section{Kesimpulan}

Penelitian ini bertujuan untuk mengetahui pengaruh jasa non-audit, lama hubungan auditor dengan klien, persaingan KAP, besar ukuran KAP, jangka waktu audit, dan relativisme terhadap independensi auditor. Sampel yang digunakan dalam penelitian ini adalah auditor yang telah memiliki pengalaman bekerja di KAP minimal 1 tahun. Berdasarkan hasil penelitian yang telah dilakukan maka dapat disimpulkan sesuai dengan rumusan masalah sebagai berikut:

1. Jasa non-audit tidak memiliki pengaruh terhadap independensi auditor.

2. Lama hubungan auditor dengan klien memiliki pengaruh terhadap independensi auditor.

3. Persaingan KAP tidak memiliki pengaruh terhadap independensi auditor.

4. Besar ukuran KAP tidak memiliki pengaruh terhadap independensi auditor.

5. Jangka waktu audit tidak memiliki pengaruh terhadap independensi auditor.

6. Relativisme tidak memiliki pengaruh terhadap independensi auditor.

\section{Keterbatasan Penelitian}

Keterbatasan yang terdapat di dalam penelitian ini yaitu sampel penelitian yang kurang luas. Berdasarkan data yang dihimpun oleh OJK per 31 Januari 2020, tercatat jumlah akuntan publik di DKI Jakarta sebanyak 763. Namun, peneliti hanya mampu memperoleh 42 kuesioner sebagai bahan 
penelitian. Hal ini menandakan bahwa hasil penelitian ini tidak dapat mewakili auditor di wilayah DKI Jakarta. Penyebaran kuesioner yang dilakukan saat jadwal kerja yang padat untuk auditor menjadi kendala utama dalam penyebaran kuesioner.

\section{Saran}

Berdasarkan kesimpulan dan keterbatasan yang dimiliki peneliti, maka disarankan sebagai berikut:

1. Bagi peneliti selanjutnya, dapat menggunakan sampel yang ukurannya lebih besar sehingga semakin mewakili populasi yang diinginkan.

2. Bagi peneliti selanjutnya, dapat melakukan analisis faktor-faktor yang mempengaruhi independensi auditor dengan menambahkan variabel lain.

Implikasi dari penelitian ini diharapkan dapat menjadi pertimbangan dan evaluasi dalam praktik profesi Akuntan Publik di Indonesia demi peningkatan kinerja dan profesionalitas, serta mendukung usaha pengedukasian masyarakat, khususnya bagi para pemakai laporan keuangan. 


\section{DAFTAR PUSTAKA}

Belarminus, Roberto. (2017). KPK Panggil Empat Pegawai BPK Terkait Kasus Suap Auditor BPK. Dikutip 2 Juli dari Kompas: https://nasional.kompas.com/read/2017/12/18/11330371/kpkpanggil-empat-pegawai-bpk-terkait-kasus-suap-auditor-bpk

Cousin, Germana., \& Ika, Ardiani. (2010). Pengaruh faktor internal dan eksternal terhadap independensi dan kualitas audit auditor di Jawa Tengah. Jurnal Ekonomi dan Bisnis, 5(9).

Ekobayong. (2004). Depkeu Bekukan Izin Dua Akuntan Publik. Dikutip 1 Juli dari BPKP: http://www.bpkp.go.id/berita/read/561/8180/Depkeu-Bekukan-Izin-Dua-Akuntan-Publik.bpkp

Lestari, Sri. (2011). Perkembangan dan Penjelasan Profesi Akuntan Publik.

Manroe, Dewi (2013). Tugas 7 Kode Etik Akuntan Publik. Wordpress. Dikutip 3 Juli dari https://dewimanroe.wordpress.com/2014/11/04/tugas-7-kode-etik-akuntan-publik/

Probowati, Wulan. (2015). Pengaruh faktor internal dan eksternal terhadap independensi dan kualitas audit auditor (Studi Empiris pada KAP di Surakarta dan Yogyakarta).

Putri, Kirana., Hardi., \& Silalahi, Sem Paulus. Analisis Faktor-Faktor yang Mempengaruhi Independensi Akuntan Publik Dalam Pelaksanaan Audit (Study Survey Pada Kantor Akuntan Publik di Pekanbaru dan Batam)

Rachmawati, Lenny. (2006). Analisis Pengaruh Independence in Fact, Independence in Appearance, dan Independence in Competence Terhadap Kualitas Audit Pada KAP Di Surabaya, Surabaya.

Rakai A.W.S, Brilian Akbar., \& Kartika, Andi. (2015). Faktor-faktor yang mempengaruhi auditor di Jawa Tengah (Studi Empiris pada Kantor Akuntan Publik di Jawa Tengah).

Setyono, Unggul. (2016). “Analisis Faktor-Faktor yang Berpengaruh Terhadap Independensi Auditor (Studi Empiris Pada Kantor Akuntan Publik Semarang)”.

Sukarno, Puput Adi. (2019). Menkeu Jatuhkan Sanksi Auditor Laporan Keuangan Garuda Indonesia, Ini Rinciannya. Dikutip 2 Juli dari Ekonomi: https://ekonomi.bisnis.com/read/20190628/9/938973/menkeu-jatuhkan-sanksi-auditor-laporankeuangan-garuda-indonesia-ini-rinciannya

Tim, CNN Indonesia. (2018). Kasus SNP Finance, Dua Kantor Akuntan Publik Diduga Bersalah. $\begin{array}{lllll}\text { Dikutip } & 2 & \text { Juli } & 2019 & \text { dari } \\ \text { CNN }\end{array}$ https://www.cnnindonesia.com/ekonomi/20180926072123-78-333248/kasus-snp-finance-duakantor-akuntan-publik-diduga-bersalah

Wurangian, Hanny. \& Muslich Anshori. (2003). "Pengaruh Faktor Internal dan Faktor Eksternal Terhadap Independensi Auditor (Studi Pada Kantor Akuntan Publik di Surabaya)”. 
Sari, M.R., Zuhri, A. \& Wijaya, P.M.N. (2021). Dilema Auditor: Faktor Internal ....

Yudiasmoro, Tondo. (2007). Faktor-Faktor yang Mempengaruhi Tingkat Independensi Penampilan Akuntan Publik. Jurusan Akuntansi, Fakultas Ekonomi, Universitas Tribhuwana Tunggadewi. Optima, 7(2), 128-135. 